\title{
KARAKTERISASI ZAT WARNA TOMAT (Solanum lycopersicum) FRAKSI METANOL:N-HEKSAN SEBAGAI PHOTOSENSITIZER PADA DYE SENSITIZED SOLAR CELL (DSSC)
}

\author{
Nur Hasbi Wahab, Aisyah, dan Suriani \\ Jurusan kimia, Fakultas Sains dan Teknologi, UIN Alauddin Makassar \\ Email: nurhasbi43@yahoo.co.id
}

\begin{abstract}
One of the potential alternative energy to be developed to overcome energy crisis in the world is an DSSC. This research aimed to make a series of Dye Sensitized Solar Cell (DSSC) using an organic dye from crude extract of tomato as a photosensitizer. The dye obtained from the maceration by of ultrasonic waves using methanol. Separation was done by KKCV using eluent of methanol: $n$-hexane (3: 7, 1: 1, 7: 3). The best efficiency value ( $\Pi$ ) in the series of DSSC that results from the fraction methanol: n-hexane (1:1) was $0.0249 \%$. Characterization using spectrophotometer UV-Vis showed a maximum absorption at wavelength of $447 \mathrm{~nm}$ which is the absorption of carotene compound. FTIR analysis showed that samples generally have $-\mathrm{CH}_{2}-, \mathrm{C}=\mathrm{C}$ and $\mathrm{OH}$ strecth wich are the characteristic of carotene compound. GCMS analysis showed that dye components which estimated is dihydroxy lycopene of the retention time 10.93 with a molecular ion peak at $\mathrm{m} / \mathrm{z} 91$.
\end{abstract}

Keywords: DSSC, efficiency, characterization, photosensitizer and Solanum lycopersicum.

\section{PENDAHULUAN}

Peningkatan kebutuhan energi yang sangat tinggi menimbulkan masalah berkaitan dengan sumber energi yang ada, hal ini disebabkan pada pasokan energi yang semakin berkurang. Berdasarkan data Badan Pengkajian dan Penerapan Teknologi Indonesia (BPPT 2014:13), tingkat komsumsi energi terus meningkat dari tahun 2000 ke 2012 khususnya energi fosil. Potensi dampak lingkungan yang paling signifikan adalah polusi dari emisi pembakaran bahan bakar fosil yang dapat memicu terjadinya global warming.

Sel surya adalah salah satu sumber energi alternatif yang sangat potensial dikembangkan. Sel surya merupakan sumber energi listrik yang dihasilkan dari sinar matahari. Energi yang dihasilkan mencapai $3 \times 10^{24}$ joule per tahun yang setara dengan $10 \%$ dari kebutuhan energi masyarakat dunia (Gratzel, 2001:338). Sel surya yang pertama dibuat menggunakan bahan silikon. Sel surya konvensional ini memiliki efisiensi tinggi, namun biaya pembuatannya relatif lebih mahal dibandingkan sel surya yang lainnya. Hal ini 
karena sel surya konvensional harus menggunakan silikon dengan tingkat kemurnian yang tinggi dan bahan-bahan kimia berbahaya dengan biaya yang besar. Oleh karena itu, dikembangkan sel surya generasi baru tanpa menggunakan silikon sehingga harganya lebih murah daripada sel surya konvensional. Perangkat ini dikenal dengan nama sel surya tersensitifikasi pewarna (SSTP) atau Dye Sensitized Solar Cell (DSSC) yang menggunakan matahari sebagai energi yang dikonversi menjadi energi listrik (O'Regan dan Gratzel, 1991:737).

DSSC adalah sel surya yang berbeda dengan sel surya pada umumnya dimana sel surya DSSC tidak menggunakan bahan silikon tetapi menggunakan bahan organik dari zat warna untuk menyerap sinar matahari. DSSC menggunakan $\mathrm{TiO}_{2}$ yang berfungsi sebagai semikonduktor (O'Regan dan Gratzel, 1991:737), Semikonduktor diberi zat warnauntuk menyerap sinar matahari. Semikonduktor tersensitasi ini berperan sebagai sebagai anoda sedangkan lapisan karbon sebagai katoda (Fitra, dkk, 2013:341). $\mathrm{TiO}_{2}$ digunakan karena sifatnya yang inert, tidak berbahaya dan harganya yang murah (Nadeak dan Susanti, 2012:81), pada penelitian yang dilakukan Trianiza dan Yodoyono (2011:7), menunjukkan nilai efisiensi dengan menggunakan ekstrak kulit jahe merah pada kaca ITO sebesar 0,0223\%.

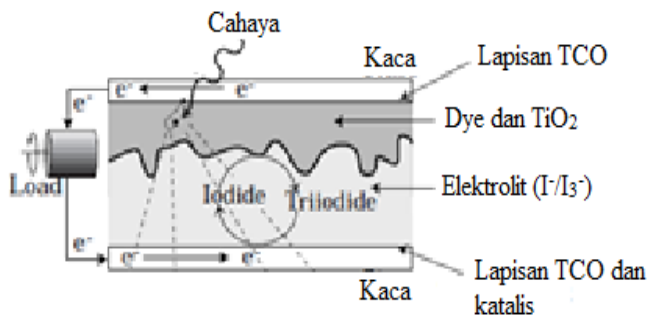

Energi cahaya yang diterima oleh zat warnamengakibatkan tereksitasinya elektron dari HOMO (High Occupied Molecular Orbital) pada zat warnake pita LUMO (Low Unoccupied Molecular Orbital) dan menyebabkan terjadinya hole pada orbital HOMO. Hole ini kemudian diregenerasi kembali oleh pemberian elektron dari larutan elektrolit, sehingga pada sisi elektroda pembanding akan bermuatan positif sedangkan pada sisi TCO yang terlapisi $\mathrm{TiO}_{2}$ mempunyai potensial negatif. Hal ini menyebabkan terjadinya perbedaan beda potensial antara kedua elektroda tersebut, sehingga terjadi aliran listrik (Gratzel, 2003:146).

Pada penelitian ini dilakukan analisis dengan menentukan nilai efisiensi DSSC menggunakan zat warna tomat (Solanum lycopersicum) sebagai photosensitizer dan melakukan karakterisasi terhadap zat warna ekstrak buah 
tomat (Solanum lycopersicum) fraksi metanol:n-heksan dengan menggunakan spektrofotometer UV-Vis, FTIR, kromatografi gas spektroskopi massa (GCMS).

\section{METODE PENELITIAN}

Alat

Alat-alat digunakan, yaitu alat spektroskopi FT-IR (Fourier Transporm Infrared), GC-MS (Gas Chromatograpy-Mass Spektroscopic), spektrofotometer UV-Vis, Scanning Electron Microscope (SEM), kromatografi kolom cair vakum, rotary vacum evaporator, reaktor ultrasonik, oven, hot plate, neraca analitik, multimeter, lux meter, gelas kimia berbagai ukuran, erlenmeyer berbagai ukuran, pipet berbagai ukuran, botol semprot, spatula, batang pengaduk dan lumpang.

\section{Bahan}

Bahan yang akan digunakan pada penelitian ini, yaitu aquades $\left(\mathrm{H}_{2} \mathrm{O}\right)$, etanol, Iodin $\left(\mathrm{I}_{2}\right)$, kaca TCO (Transparent Conductive Oxide), kalium iodida (KI), $\mathrm{TiO}_{2}$, Metanol, n-heksan, pensil, silika gel tipe 7730 dan 7733, selotip dan tomat.

\section{Prosedur Kerja}

\section{Ekstraksi dan Pemurnian}

Ekstraksi zat warna tomat

Sampel buah tomat disiapkan sebanyak $3 \mathrm{Kg}$. Sampel tomat dipotong lalu dikeringkan dalam oven dengan suhu $70^{\circ} \mathrm{C}$ selama 8 jam. Sampel kering dihaluskan hingga menjadi serbuk kemudian ditambahkan pelarut metanol $\left(\mathrm{CH}_{3} \mathrm{OH}\right)$ ke dalam sampel. Sampel diekstraksi dengan alat ultrasonik selama 16 menit. Ekstrak yang diperoleh disaring dan dimasukkan ke dalam rotary vacum evaporator lalu diuapkan hingga diperoleh ekstrak kental.

\section{$K K C V$}

Silika gel tipe 7730 dimasukkan ke dalam kolom KKCV lalu diratakan ke seluruh bagian dengan menggunakan spatula. Lalu dimasukkan pelarut $n$ heksan hingga melewati seluruh silika gel. Permukaan silika gel ditutup dengan kertas saring yang disesuaikan dengan kolom KKCV. Kemudian ditimbang silika gel tipe 7733 sebanyak 3 gram. Ekstrak kental tomat diteteskan ke dalam silika gel yang telah ditimbang. Silika gel diimpregnasi dengan ekstak kental ke 
dalam kolom KKCV yang telah dilapisi kertas saring dan dialiri dengan eluen metanol : n-heksan $(3: 7,1: 1,7: 3)$.

\section{DSSC}

Pembuatan lapisan tipis $\mathrm{TiO}_{2}$

Ditimbang 10 gram serbuk $\mathrm{TiO}_{2}$ yang telah digerus dengan mortar. Ditambahkan air secukupnya dan dipanaskan, kemudian disaring. Ditambahkan $5 \mathrm{~mL}$ etanol dan diaduk sampai didapatkan pasta yang homogen.

\section{Pembuatan elektrolit}

Ditiimbang 0,83 gram KI lalu dilarutkan dalam $10 \mathrm{~mL}$ air. Kemudian ditambahkan 0,127 gram $\mathrm{I}_{2}$ yang diaduk homogen.

\section{Pembuatan elektroda pembanding}

Kaca TCO dilapisi dengan cara menggoreskan pensil. Selanjutnya dipanaskan dengan lilin hingga berwarna hitam.

\section{Rangkaian DSSC}

Pasta $\mathrm{TiO}_{2}$ diratakan pada kaca TCO menggunakan spatula atau pipa kapiler. kaca TCO direrndam ke dalam ekstrak warna tomat lalu ditempelkan dengan elektroda pembanding. Diteteskan larutan elektrolit pada kedua elektroda. Rangkaian DSSC diukur arus dan tegangan dengan multimeter. Lux meter digunakan untuk mengukur intensitas cahaya dari matahari. Lapisan $\mathrm{TiO}_{2}$ yang telah ditetesi zat warna dianalisis pada Scanning Electron Microscope (SEM).

\section{Karakterisasi Ekstrak Buah Tomat}

Hasil fraksi dari pemurnian dikarakterisasi dengan menggunakan Spektfotometer UV-Vis, Spektrofotometer Inframerah (FT-IR), Kromatografi gas spektroskopi massa (GC-MS). 


\section{HASIL DAN PEMBAHASAN}

\section{Efisiensi DSSC}

\begin{tabular}{ccccc}
\hline No & Zat warna & $\begin{array}{c}\mathbf{P}_{\text {in }} \\
\left(\mathbf{m W a t t} / \mathbf{c m}^{2}\right)\end{array}$ & $\begin{array}{c}\mathbf{P}_{\max } \\
\left(\mathbf{m W a t t} / \mathbf{c m}^{2}\right)\end{array}$ & $\mathbf{\eta ( \% )}$ \\
\hline 1 & Ekstrak kental & 12,43106 & 0,000499 & 0,004013 \\
\hline 2 & $\begin{array}{c}\text { Metanol:n-heksan } \\
(3: 7)\end{array}$ & 12,606762 & 0,0010404 & 0,008252 \\
& & & 0,024978 \\
\hline 3 & $\begin{array}{c}\text { Metanol:n-heksan } \\
(1: 1)\end{array}$ & 12,401774 & 0,0030935 & 0,010913 \\
& & & \\
\hline 4 & $\begin{array}{c}\text { Metanol:n-heksan } \\
(7: 3)\end{array}$ & 12,679972 & 0,001384 & \\
\hline
\end{tabular}

Dari data di atas dapat terlihat bahwa nilai efisiensi yang terbaik dari rangkaian DSSC adalah ekstrak tomat hasil KKCV dengan perbandingan eluen metanol:n-heksan (1:1) yaitu 0,0249\%.

\section{Analisis Spektrofotometer UV-Vis}

Karakterisasi zat warna ekstrak tomat menggunakan spektrofotometer UV-Vis adalah untuk mengetahui panjang gelombang ekstrak tomat hasil KKCV dengan eluen metanol:n-heksan (1:1).

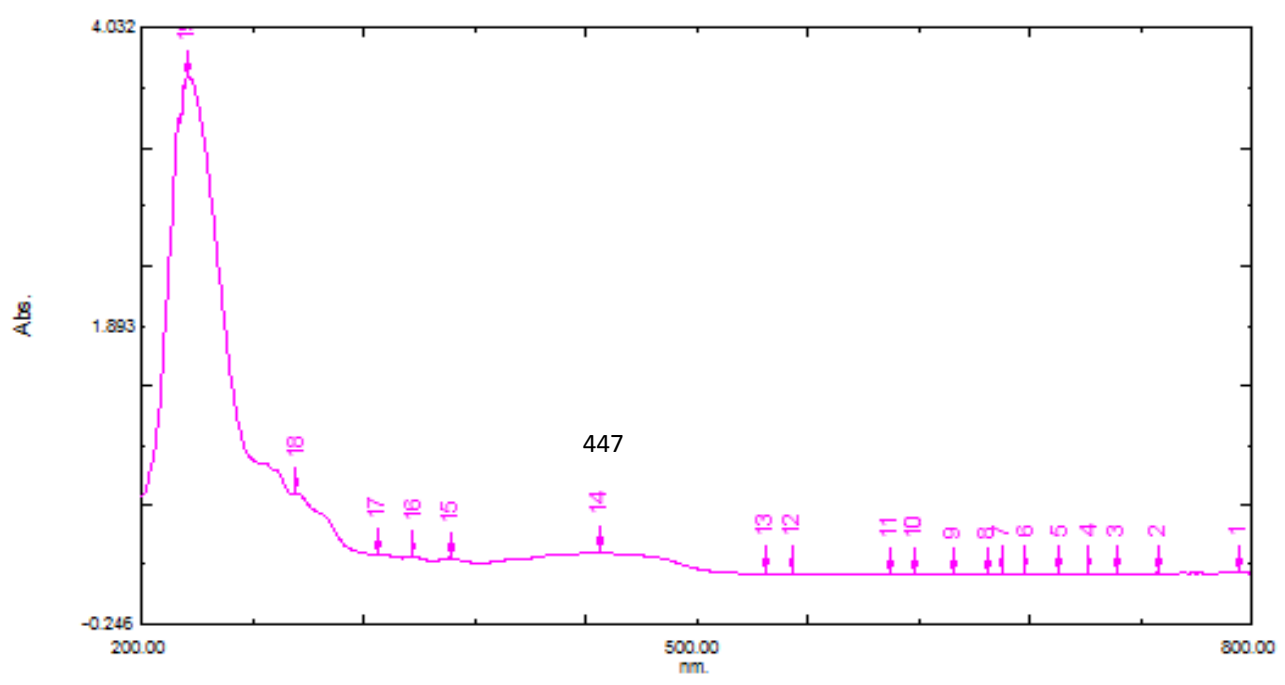

Gambar 2.Spektrum UV-Vis Ekstrak Tomat Hasil KKCV Eluen Metanol:nHeksan (1:1) 
Analisis spektrofotometer UV-Vis pada rentang panjang gelombang 200-800 nm. Puncak tertinggi terdapat pada panjang gelombang 447, 367, 284 dan $224 \mathrm{~nm}$, data ini menunjukkan adanya serapan pada panjang gelombang daerah ultraviolet (UV) dan daerah visible.

\section{Analisis FTIR}

Analisis spektrofotometri inframerah dilakukan untuk mengetahui gugus fungsional yang terdapat pada sampel ekstrak tomat hasil KKCV dengan eluen metanol : n-heksan (1:1).

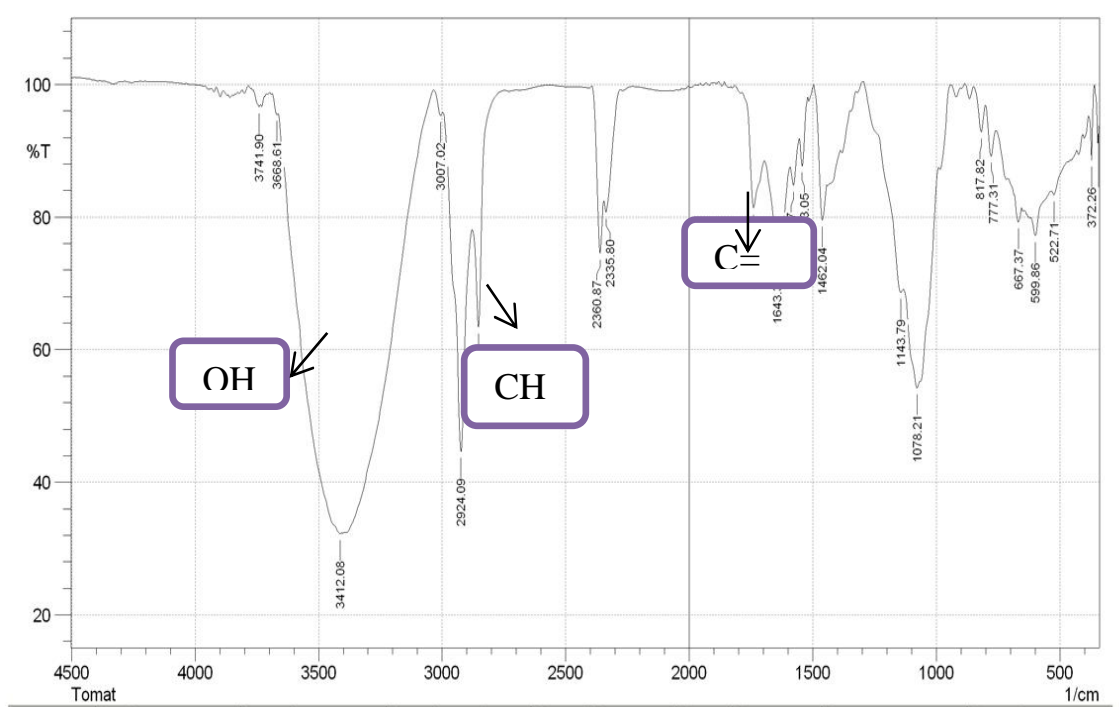

Gambar 3. Spektrum FTIR Ekstrak Tomat Hasil KKCV Eluen Metanol nHeksana $(1: 1)$

Spektrum gambar menunjukkan senyawa yang dianalisis memiliki gugus fungsi dengan puncak serapan pada bilangan 2924,09 dan $2852,72 \mathrm{~cm}^{-1}$ dengan intensitas puncak serapan kuat, serapan ini diduga dihasilkan dari ikatan C-H dari gugus metilen (- $\left.\mathrm{CH}_{2-}\right)$ (Supratman, 2010:82). Uluran tak simetrik gugus $-\mathrm{CH}_{2}$ - terletak di daerah bilangan gelombang $2924 \mathrm{~cm}^{-1}$ sedangkan uluran simetrik gugus $-\mathrm{CH}_{2}$ - terletak di daerah bilangan gelombang $2852 \mathrm{~cm}^{-1}$. Bilangan gelombang 1643 dan $1739 \mathrm{~cm}^{-1}$ adanya ikatan $\mathrm{C}=\mathrm{C}$. Bilangan gelombang $3412 \mathrm{~cm}^{-1}$ menunjukkan gugus $\mathrm{O}-\mathrm{H}$ vibrasi stretching. 
Dengan demikian, sampel diidentifikasi memiliki ikatan rangkap terkonjugasi. Gugus fungsi $\mathrm{CH}_{2}$ dan $\mathrm{C}=\mathrm{C}$ yang muncul pada spektrum FTIR diperkirakan berasal dari senyawa karoten.

\section{Analisis GCMS}

Spektrum hasil analisis terdapat pada Gambar di bawah ini.

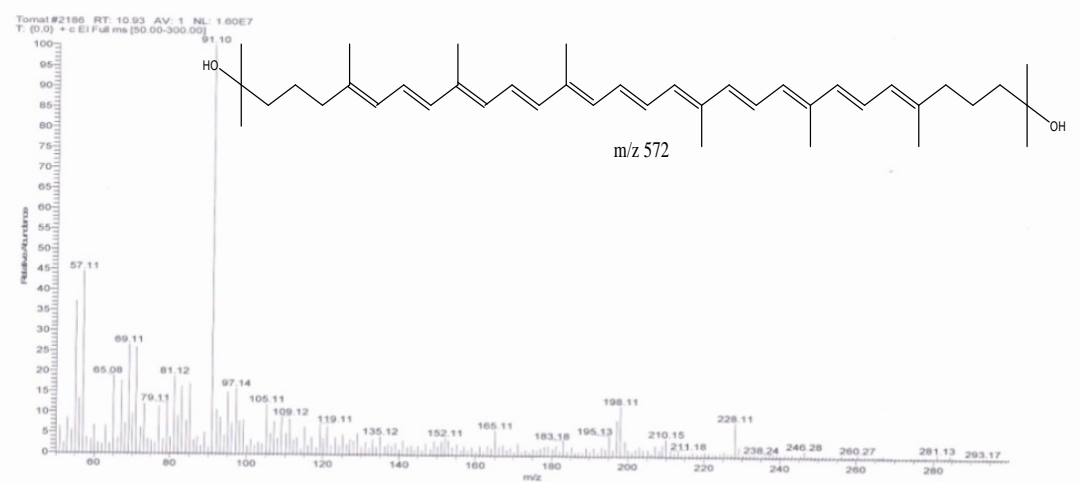

Gambar 4. Spektrum Hasil Analisis

Ion molekul dengan $\mathrm{m} / \mathrm{z} 91$ merupakan potongan fragmen pada senyawa karotenoid asiklik seperti dihidroksi likopen dengan kelimpahan $100 \%$ dan merupakan ciri khas senyawa tersebut (Enzel dan Francis, 1969:727). Senyawa pada ion molekul m/z 91 merupakan fragmen senyawa ion tropilium $\left(\mathrm{C}_{7} \mathrm{H}_{7}{ }^{+}\right)$.

\section{Scanning Electron Microscopy (SEM)}

Pengujian SEM dilakukan untuk mengetahui morfologi dari $\mathrm{TiO}_{2}$ yang telah ditambahkan dengan zat warna.

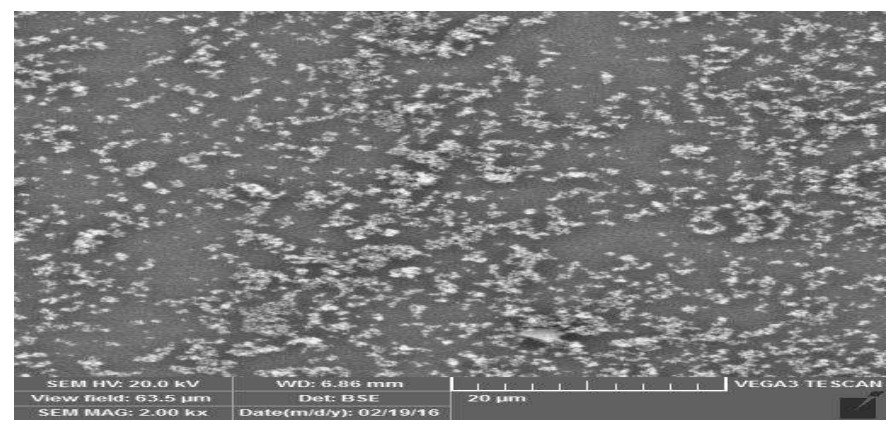

Gambar 5. Morfologi $\mathrm{TiO}_{2}$ dan Zat Warna 
Hasil pengujian Scanning Electron Microscopy (SEM) pada gambar di atas menunjukkan morfologi lapisan $\mathrm{TiO}_{2}$ dan zat warna. Dapat dilihat banyaknya zat warna yang terikat pada pori-pori $\mathrm{TiO}_{2}$ dengan skala $20 \mu \mathrm{m}$. Zat warna telah meresap pada lapisan tetapi tidak tersebar merata di permukaan $\mathrm{TiO}_{2}$. Hal ini menunjukkan adanya interaksi antara $\mathrm{TiO}_{2}$ dan zat warna.

\section{PENUTUP}

\section{Kesimpulan}

Nilai efisiensi (П) terbaik adalah zat warna ekstrak tomat hasil KKCV dengan eluen metanol:n-heksan (1:1) sebesar 0,0249\%. Karakterisasi menggunakan spektrofotometer UV-Vis menunjukkan serapan maksimal pada panjang gelombang $447 \mathrm{~nm}$. Analisis FTIR menunjukkan pada umumnya sampel memiliki ikatan $-\mathrm{CH}_{2}-, \quad \mathrm{C}=\mathrm{C}$ dan $\mathrm{OH}$. Hasil analisis GCMS menunjukkan komponen zat warna ekstrak tomat yang diduga merupakan dihidroksi likopen.

\section{DAFTAR PUSTAKA}

Enzell, Francis G.W., 1969,Mass Spectrometric Studies Of Carotenoids, Acta Chemica Scandinavica,727-750.

Fitra, et. al., 2013, Dye Solar Cell Using Syzigium Oleina Organic Dye,Energy Procedia,36: 341-348.

Gratzel, M., Smestad, and Gred, P., 1998,Demonstrating Electron Transfer and Nanotechnology: A Natural Dye-Sensitized Nanocrystalline Energy Converter, Journal of Chemical Education,75(6): 752-757.

Gratzel, M., 2003, Photoelectrochemical Cells,Nature, 414: 338-344.

Gratzel, M., 2003, Dye-Sensitized Solar Cells,Journal Photochemistry and Photobiology, 4: 145-153.

Nadeak, Sahat Marthua Reynard,dan Diah Susanti, 2012,Variasi Temperatur dan Waktu Tahan Kalsinasi terhadap Unjuk Kerja Semikonduktor $\mathrm{TiO}_{2}$ sebagai Dye Sensitized Solar Cell (DSSC) dengan Dye dari Ekstrak Buah Naga Merah,Jurnal Teknik ITS, 1: 81-86.

O'Regan, Brian, Gratzel, and Michael, 1991, A low-Cost, High-Efficiency Solar Cell based On Dye-Sensitized Colloidal $\mathrm{TiO}_{2}$ Films,Nature, 353: 737-740.

Supratman, Unang., 2010,Elusidasi Struktur Senyawa Organik, Jakarta: Widya Padjajaran. 
Nur Hasbi Waha6, Aisyah, dan Suriani

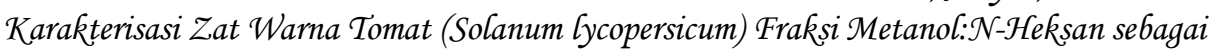
Photosensitizer pada Dye Sensitized Solar Cell (DSSC)

Triniza, Ice, dan Yodoyono, 2011,Fabrikasi DSSC dengan Teknik Pelapisan Spin Coating Menggunakan Kaca ITO dan FTO sebagai Substrat dan Variasi Jahe Merah Sebagai Dye Sensitizer, Surabaya: Institut Teknologi Sepuluh November. 